\title{
Prevalence of hepatitis A IgG in individuals with chronic hepatitis $B$ infection in Babol
}

M.R.H. Roushan, ${ }^{1}$ A. Bijani, ${ }^{2}$ R. Saghe ${ }^{2}$ and O. Jazayeri ${ }^{3}$

$$
\begin{aligned}
& \text { معدل انتشار الغلوبولين المناعي IgG للالتهاب الكبدي "أ" للدى مرضى الالتهاب الكبدي "بي" المزمن }
\end{aligned}
$$

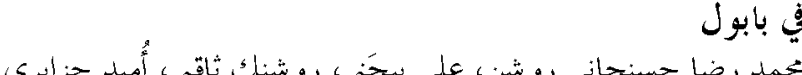

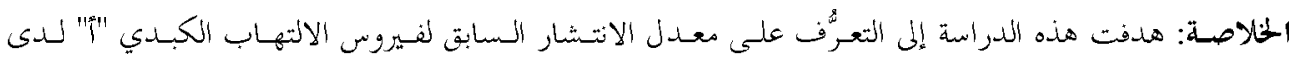

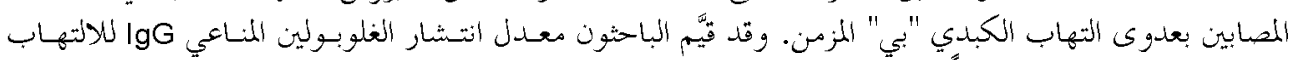

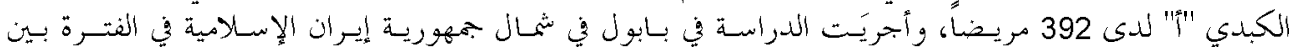

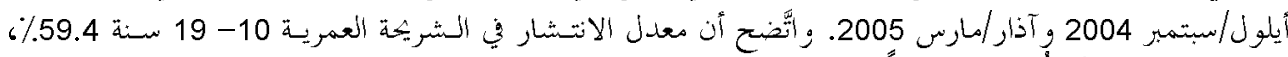

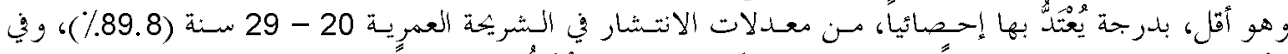

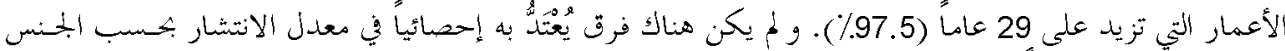

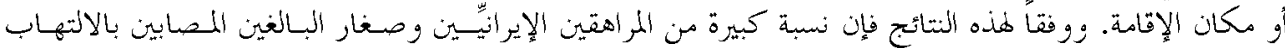

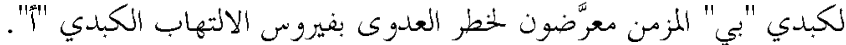

ABSTRACT To determine the prevalence of previous hepatitis A virus (HAV) infection in people chronically infected with hepatitis B virus (HBV), we assessed the prevalence of anti-HAV IgG in 392 patients. The study was carried out in Babol, northern Islamic Republic of Iran from September 2004 to March 2005. Prevalence in those aged $10-19$ years was $59.4 \%$ and was significantly lower than that in those aged $20-29$ years (89.8\%) and those over 29 years $(97.5 \%)$. There was no significant difference in prevalence according to sex or place of residence. A significant proportion of Iranian adolescents and young adults with chronic HBV infection are at risk of contracting HAV infection.

Prévalence des IgG anti-hépatite $A$ chez les sujets atteints d'hépatite $B$ chronique à Babol RÉSUMÉ Afin de déterminer la prévalence d'une infection antérieure par le virus de l'hépatite $A(V H A)$ chez des sujets atteints d'une hépatite $B$ chronique, nous avons évalué la prévalence des IgG anti-VHA chez 392 patients. Cette étude a été menée entre septembre 2004 et mars 2005 à Babol, dans la partie septentrionale de la République islamique d'Iran. Nous avons constaté une prévalence de $59,4 \%$ dans la tranche d'âge 10-19 ans, significativement inférieure à celle enregistrée chez les 20-29 ans (89,8\%) et les plus de 29 ans $(97,5 \%)$. Cette prévalence n'a laissé apparaître aucune différence significative en fonction du sexe ou du lieu de résidence. Un pourcentage significatif d'adolescents iraniens et de jeunes adultes atteints d'hépatite $B$ chronique sont exposés au risque de contracter une infection due au VHA.

\footnotetext{
Department of Infectious Diseases, Yahyanejad Hospital; ${ }^{2}$ Department of Medical Research, Babol University of Medical Sciences, Babol, Islamic Republic of Iran (Correspondence to M.R.H. Roushan: hagar2q@yahoo.ca).

${ }^{3}$ Department of Biology, Mazandaran University, Babolsar, Islamic Republic of Iran

Received: 12/05/05; accepted 13/09/05
} 


\section{Introduction}

Hepatitis A has a worldwide distribution and is typically an infection of childhood that is more common under conditions of crowding and poor hygiene [1]. Virtually all adults living in certain areas of the Mediterranean basin, Africa and many parts of Asia or other parts of the developing world show evidence of past infection [1,2]. The severity of clinical symptoms following hepatitis A virus (HAV) infection is agedependent: hepatitis A in children is mostly an asymptomatic disease, while adolescents and adults usually show symptoms of clinical hepatitis. There is conflicting evidence from a growing number of studies indicating that hepatitis A infection may have a more severe course and a higher fatality rate when superimposed on patients with underlying liver disease, including hepatitis B virus (HBV) infection, than patients having acute hepatitis A alone [3-6]. During a hepatitis A epidemic in Shanghai in 1988, the mortality rate from acute hepatitis A in carriers of hepatitis B surface antigen (HBsAg) was 5.6 times greater than that in non-carriers [7].

Although the age of exposure to hepatitis A has been increasing in the Islamic Republic of Iran, children and young adults remain the primary target. The seroprevalence of hepatitis $\mathrm{A}$ in children younger than 15 years has been reported as $22.3 \%$ [ 8 ].

Hepatitis A infection may have a more severe course and a higher fatality rate when superimposed on patients with chronic HBV infection. The purpose of this study was, therefore, to assess the seroprevalence of previous HAV infection (anti-HAV IgG) in $\mathrm{HBV}$-infected individuals in our region.

\section{Methods}

This study was carried out at the Department of Infectious Diseases at Yahyanejad
Teaching Hospital, Babol Medical University. This department serves $>1.5$ million people living the cities of Babol and Amol and the surrounding villages. During the period September 2004-March 2005 we recruited into the study HBsAg positive individuals $\geq 10$ years of age, who were attending the department. The hepatitis B section of the department monitors more than 3000 cases of chronic HBV-infected individuals. Follow-up includes testing for HBsAg, $\mathrm{HBe}$ antigen ( $\mathrm{HBeAg}$ ), aspartame aminotransferase, alanine aminotransferase and $\alpha$-fetoprotein, which are performed at 6-month intervals.

Sample size was estimated as 384 , based on $80 \%$ mean prevalence of anti-HAV IgG in the general population reported in many developing countries [9-12] and allowing for $4 \%$ maximum error. We increased this to 392 to allow for possible cases of antiHAV IgM positive individuals and maintain the sample size. HBsAg positive individuals are followed up at 6-month intervals to check their chronic HBV infection status. We selected all consecutive cases $\geq 10$ years old who were referred for monitoring of their condition until the sample size was reached.

The university ethics committee approved the study and all the patients gave their informed consent. There were no refusals to participate.

A $3 \mathrm{~mL}$ blood sample was taken from each participant. Sera were obtained by centrifuging all blood samples (Sigma Laborzentrifugen, Osterode, Germany) with relative centrifugal force $1122 \mathrm{~g}$. The sera were stored at $-20^{\circ} \mathrm{C}$ in a refrigerator.

When all serum samples were collected, they were tested using enzyme-linked immunosorbent assay (ELISA) for anti-HAV IgG (DiaSorin, Vercelli, Italy). Estimation of anti-HAV IgM and total antibodies to hepatitis A were done in all cases. Sera 
testing positive for total anti-HAV and IgM were excluded from the study. Samples testing negative for anti-HAV IgM and positive for total anti-HAV were considered antiHAV IgG-positive. Cut-off levels for the 5 ELISA kits used for testing the 392 samples ( $\sim 90$ samples tested for each kit) for total anti-HAV were calculated as $0.438,0.564$, 0.697, 0.686 and 0.700, respectively.

Data were analysed with SPSS, version 13. Chi-squared and Fisher exact tests were used to compare data.

\section{Results}

The sample comprised 392 patients. Mean age was 29.0 (standard deviation 11.6) years (range 10-70 years). There were 158 $(40.3 \%)$ patients aged $>29$ years (Table 1$)$. About one third of the participants were from urban areas (Table 1).

All samples were negative for anti-HAV IgM; 332 (84.7\%) were HBsAg and anti$\mathrm{HBe}$ positive and 60 (15.3\%) were $\mathrm{HBeAg}$ positive.

Overall prevalence of anti-HAV IgG was $82.1 \%$. Prevalence was greatest in those

\begin{tabular}{|c|c|c|c|}
\hline \multirow{2}{*}{$\begin{array}{l}\text { Characteristic } \\
\text { Age group (years }\end{array}$} & \multicolumn{2}{|c|}{ No. of cases } & $\%$ \\
\hline & & & \\
\hline $10-19$ & 106 & 63 & 59.4 \\
\hline 20-29 & 128 & 115 & 89.8 \\
\hline$>29$ & 158 & 154 & 97.5 \\
\hline \multicolumn{4}{|l|}{ Sex } \\
\hline Male & 231 & 192 & 83.1 \\
\hline Female & 161 & 130 & 80.7 \\
\hline \multicolumn{4}{|l|}{ Residence } \\
\hline Urban & 134 & 110 & 82.1 \\
\hline Rural & 258 & 212 & 82.2 \\
\hline
\end{tabular}

aged $>29$ years, $97.5 \%$. Seroprevalence in those aged 10-19 years was significantly lower than in the other 2 age groups $(P$ $<0.0001$ ) (Table 1).

Seropositivity was similar in males and females and for urban and rural residence.

\section{Discussion}

In this study, the pattern of infection with regard to age was comparable with previous reports of past HAV infection in other developing countries $[9,10,13,14]$. The low prevalence of HAV infection in patients younger than 20 years in our region shows that changes in the epidemiology of infection have occurred in recent years. According to a study which was performed in 1997 in our region, seroprevalence was $85 \%$ in children under 15 years [15]. In a study conducted in Zabol province in the same year on individuals aged 10-19 years, prevalence of anti-HAV was 95\% [16]. In another 1997 study, seroprevalence of anti-HAV in children under 14 years was $81 \%$ [17].

In developed countries in recent years, there has been a shift in the prevalence pattern of hepatitis A virus (HAV) infection from a younger to an older age group. This has been attributed to improvements in socioeconomic conditions and hygiene [18-24].

Hong Kong, Malaysia, Singapore, Taiwan and Thailand have also experienced a decline in childhood and adolescent HAV seroprevalence typical of countries which have undergone socioeconomic development. In the Philippines and Vietnam, agerelated seroprevalence patterns are typical of high to moderate endemicity [25].

Data on the endemicity of HAV infection in Africa and the Middle East are scant, but most of the African countries appear to have high endemicity, with the exception 
of subpopulations in certain areas. In Saudi Arabia, shifting HAV epidemiology has been documented in recent years. Similar findings have been reported from other countries in the Region [26]. In Turkey, the seroprevalence was $37.3 \%$ in $11-14$-year olds and $43.2 \%$ in $15-19$-year olds and seropositivity increased with age [27-29]. Data from 6 countries in South America showed that the epidemiology is shifting from high to intermediate endemicity, with the population susceptible to HAV infection shifting from children to adolescents and adults [10]. Some developing countries have high endemicity for HAV: seroprevalence has been reported at $>95 \%$ in people younger than 20 years [12,30].

Hepatitis A, an enterically transmitted disease, shows distinct association with socioeconomic status, populations with improved socioeconomic status experiencing lower exposure to the virus. With the varied epidemiological patterns and economical constraints in different countries, however, it does not seem to be possible to evolve a universal policy for immunization.

It has been proposed that, irrespective of endemicity of hepatitis A, high-risk groups such as HBV infected individuals should be immunized with hepatitis A vaccine
[5,6,31]. Approximately, 5\% of the world's population has chronic HBV infection, and most of these live in developing countries [32]. Vaccination of these patients against $\mathrm{HAV}$ is necessary and is related to HAV seroprevalence in each country. In regions with intermediate HAV prevalence, testing for previous HAV infection is not necessary and there is no cost-benefit in HBV-infected individuals aged $\geq 20$ years. Testing should be limited to patients $<20$ years, and those testing negative should be given HAV vaccine.

Our findings indicate that a significant proportion of the Iranian adolescent and adult population with $\mathrm{HBV}$ infection may be at risk of HAV infection. Thus, HAV prevaccination screening in our region must be limited to people younger than 20 years.

\section{Acknowledgements}

This study was supported by a grant from Babol Medical Research Centre. The authors would like to thank the entire personnel and the staff of Razi Laboratory for obtaining blood samples and performing the laboratory tests.

\section{References}

1. Feinstone SM, Gust ID. Hepatitis A. In: Mandell GL, Bennett JE, Dolin R, eds. Principles and practice of infectious diseases, 5th ed. Philadelphia, Churchill Livingstone, 2000, 2:1920-40.

2. Shapiro $\mathrm{CN}$ et al. Epidemiology of hepatitis $A$ in the United States. In: Hollinger FB, Lemon SM, Margolis HS, eds. Viral hepatitis and liver disease. Baltimore, Williams \& Wilkins, 1991:71.

3. Keeffe FB. Is hepatitis A more severe in patients with chronic hepatitis $B$ and other chronic liver disease? American journal of gastroenterology, 1996, 90:201-5.

4. Vento $S$ et al. Fulminant hepatitis associated with hepatitis $A$ virus superinfection in patients with chronic hepatitis $\mathrm{C}$. New England journal of medicine, 1998, 338(5):286-90.

5. Pramoolsinsap $C$ et al. Acute hepatitis $A$ super-infection in HBV carriers, or chronic liver disease related to HBV or HCV. Annals of tropical medicine and parasitology, 1999, 93(7):745-51. 
6. Tsang SW, Sung JJ. Inactivated hepatitis $A$ vaccine in Chinese patients with chronic hepatitis B infection. Alimentary pharmacology \& therapeutics, 1999, 13(11):14459.

7. Yao G. Clinical spectrum and natural history of viral hepatitis A in a 1988 Shanghai epidemic. In: Hollinger FB, Lemon SM, Margolis $\mathrm{H}$, eds. Viral hepatitis and liver disease. Baltimore, Williams \& Wilkins, 1991:76-8.

8. Mehr AJ et al. Age-specific seroprevalence of hepatitis $A$ infection among children visited in pediatric hospitals of Tehran, Iran. European journal of epidemiology, 2004, 19(3):275-8.

9. Das $\mathrm{K}$ et al. The changing epidemiological pattern of hepatitis $A$ in an urban population of India: emergence of a trend similar to the European countries. European journal of epidemiology, 2000, 16(6):507-10.

10. Tapia-Conyer $R$ et al. Hepatitis A in Latin America: a changing epidemiologic pattern. American journal of tropical medicine \& hygiene, 1999, 61(5):825-9.

11. Wong $\mathrm{KH}$ et al. Epidemiology of hepatitis $A$ and $E$ infection and their determinants in adult Chinese community in Hong Kong. Journal of medical virology, 2004, 72(4):538-44.

12. Antaki N, Kebbewar MK. Hepatitis A seroprevalence rate in Syria. Tropical doctor, 2000, 30(2):99-101.

13. Joshi N, Yr NK, Kumar A. Age related seroprevalence of antibodies to hepatitis A virus in Hyderabad, India. Tropical gastroenterology, 2000, 21(2):63-5.

14. Mall ML et al. Seroepidemiology of hepatitis A infection in India: changing pattern. Indian journal of gastroenterology, 2001, 20(4):132-5.

15. Saffar MJ, Hammatabadi MA. [Seroepidemiological study on hepatitis A in different age groups of children in Sari during
1997-98]. Nammeh daneshgah, 1999, 9 (22/23):1-5 [in Farsi].

16. Salehi M, Sanei ME. [Seroepidemiology of hepatitis $A$ in population under 30 years old in rural area of Zabol]. Journal of Medical Faculty, Guilan University of Medical Sciences, 2001, 10(39/40):26-9 [in Farsi].

17. Alborzi P. [Age groups who need gamma globulins in contact with hepatitis A]. Paper presented at the 7th Congress on Infectious Diseases and Tropical Medicine, Babolsar, Islamic Republic of Iran, 1998 [in Farsi].

18. Dal-Ré R, García-Corberia P, García-deLomas J. A large percentage of the Spanish population under 30 years of age is not protected against hepatitis A. Journal of medical virology, 2000, 60(4):363-6.

19. Gonzalez A et al. Encuesta seroepidemiológica de prevalencia de anticuerpos antihepatitis $A$ en la población adulta joven española [Seroepidemiologic survey of hepatitis A antibodies in the young adult Spanish population]. Medicina clinica, 1994, 103(12):445-8.

20. Polz-Dacewicz MA, Policzkiewicz P, Badach Z. Changing epidemiology of hepatitis A virus infection-a comparative study in central eastern Poland (1990-1999). Medical science monitor, 2000, 6(5):989-93.

21. Moschen ME et al. Hepatitis A infection: a seroepidemiological study in young adults in North-East Italy. European journal of epidemiology, 1997, 13(8):875-8.

22. Roy E et al. Seroprevalence and risk factors for hepatitis A among Montreal street youth. Canadian journal of public health, 2002, 93(1):52-3.

23. Catania $S$ et al. Studio sieroepidemiologico della prevalenza degli anticorpi anti HAV nei bambini di Roma e Provincia [Seroepidemiologic study of the prevalence of anti-HAV antibodies in children 
in Rome]. Revista europea per le scienze mediche e farmacologiche, 1996, 18(1):7-9.

24. Santana OE et al. Estudio seroepidemiológico de hepatitis A en Gran Canaria [Seroepidemiological study of hepatitis A in Gran Canaria (Spain)]. Enfermedades infecciosas y microbiologia clinica, 2000, 18(4):170-3.

25. Kunasol P et al. Hepatitis A virus: declining seroprevalence in children and adolescents in Southeast Asia. Southeast Asian journal of tropical medicine and public health, 1998, 29(2):255-62.

26. Tufenkeji H. Hepatitis A shifting epidemiology in the Middle East and Africa. Vaccine, 2000, 18(Suppl. 1):S65-7.

27. Erdogan MS et al. The epidemiology of hepatitis $A$ virus infection in children, in Edirne, Turkey. European journal of epidemiology, 2004, 19(3):267-73.

28. Sidal $M$ et al. Age-specific seroepidemiology of hepatitis $A, B$, and $E$ infections among children in Istanbul, Turkey. European journal of epidemiology, 2001, 17(2):141-4.

29. Colak D et al. Seroprevalence of antibodies to hepatitis $A$ and $E$ viruses in pediatric age groups in Turkey. Acta microbiologica et immunologica hungarica, 2002, 49(1):93-7.

30. Foussal MD, Picon C, Sorrentino A. Hepatitis $A$ en la infancia. La punta del iceberg infectológico [Hepatitis A in childhood. The tip of an infectious disease iceberg]? Acta gastroenterologica latinoamericana, 2002, 32:101-5.

31. Arankalle VA, Chadha MS. Who should receive hepatitis $A$ vaccine? Journal of viral hepatitis, 2003, 10(3):157-8.

32. Mahoney FJ. Update on diagnosis, management, and prevention of hepatitis $B$ virus infection. Clinical microbiology reviews, 1999, 12(2)357-66. 